\title{
DEVELOPMENT AND TESTING OF THE TECHNOLOGY OF PRODUCTION OF THE BEEBREAD WITH THE USE OF ARTIFICIAL COMBS
}

\author{
Brovarskyi Valerii ${ }^{1}$, Velychko Serhii ${ }^{1},{\text { Brindza } \operatorname{Jan}^{2} \text {, Adamchuk Leonora }}^{1}{ }^{*}$ \\ ${ }^{1}$ National University of Life and Environmental Sciences of Ukraine, Kyiv, Ukraine
${ }^{2}$ Institute of Biodiversity Conservation and Biosafety, Slovak University of Agriculture in Nitra, Slovak Republic
}

Received 25. 6. 2017

Revised 29.6. 2017

Published 24.11.2017

Until recently, the main mass of beebread was lost in the process of melting raw and used as material and only its minor portion was used by beekeepers for their own needs. This was mostly due to considerable time to remove beebread from combs as well as bad preservation in the condition of normal environment. However, nowadays with the increase in demand for this kind of product of beekeeping, scientists and practitioners are interested in the development of the technologies of beebread production. The aim of our work was to develop new technological equipment for bee bread production of using artificial comb. Research and construction equipment and its testing were conducted during 2011-2016. The bases of scientific research were "Research Apiary of Holosiievo" of the Department of Horse-Breeding and Beekeeping of the National University of Life and Environmental Sciences of Ukraine (Ukraine) and Institute of Biodiversity Conservation and Biosafety of the Slovak University of Agriculture in Nitra (Slovak Republic). Approval of new industrial technology was carried out on bee-farms of different forms of ownership in Ukraine. Currently, this technology is patented (no. UA71320) and used by beekeepers in Ukraine. The plastic cartridges were developed, which with the help of holders can be easily connected to each other and forming an artificial comb. One side of the comb is assembled from individual cartridges $(435 \times 300 \mathrm{~mm}, 300 \times 435 \mathrm{~mm}, 435 \times 230 \mathrm{~mm})$, then a polyethylene Backlit membrane (PET) with the thickness of $0.36 \mathrm{~mm}$ is put over and serves as a partition. Then the second side is put over the membrane. The cartridges assembled into the comb are connected to each other with holders. Such comb after filling bee pollen is put into the bee family nest to obtain the beebread. After the comb gets filled with beebread, it is removed from the hive, then the cartridges are separated and the content of the cells is ejected. After ripening of the bee bread for two weeks, comb removed from the hive, the cartridges are then separated and the content of the cells is ejected. We were also designed and constructed manual and mechanized device for bee pollen compression and beebread removing.

Keywords: beebread; artificial comb; production technology; manual and mechanized device

\section{Introduction}

Until recently, the main mass of beebread was lost in the process of melting raw and used as material and only its minor portion was used by beekeepers for their own needs. This was mostly due to considerable time to remove beebread from combs as well as bad preservation in the condition of normal environment. However, nowadays with the increase in demand for this kind of product of beekeeping, scientists and practitioners are interested in the development of the technologies of beebread production.

\footnotetext{
*Corresponding author: Leonora Adamchuk, National University of Life and Environmental Sciences
} of Ukraine, Kyiv, Ukraine, $\triangle$ leonora.adamchuk@gmail.com 
During the planning of obtaining the beebread, first of all the favorable conditions are organized for bees to prepare it (Бабич і Мегедь, 1979; Броварський і Багрій, 1995; Поліщук і Акумова, 1998; Brovarski et al., 2010; Величко, 2015).

Thus, in the radius of productive flight, bees have to be provided with sufficient number of protein feed sources, i.e. the flowering of polliniferous plants those produce highly-nutritional pollen (Таранов, 1986; Богомолов, 2012; Боярчук, 2015). It has been proved, that pollen-giving bees more intensively prepare bee pollen from plants, which produce pollen of a high nutritious value. Apart from that, the optimal conditions for the development of bee family are created (Жоржускене и Кждзяускене, 1990; Балабушка, 2010; Brovarski et al., 2010; Brindza et al., 2013, 2015; Nikolaieva et al., 2014; Redina et al., 2016). Thus, it is necessary for a bee family to be strong, to have a big amount of brood and a young queen bee (Броварський і Багрій, 1995; Гречка, 2011; Прибылова и Иванов, 2011).

V. F. Nekrashevych, R. A. Mamonov, T.V.Torzhenova (Приймак, 2008) recommend to harvest beebread combs in the next periods of the year: during the spring inspection of bee families, when bees start to intensively gather the bee pollen (the old beebread combs can be ejected from the bee hive without dealing harm to the family); during the summer period under certain provision conditions the combs with fully sealed beebread cells are collected; during the autumn period with the formation of nests for families before winter. Then the general method of beebread combs preparation is used. The empty dark-brown and dark combs, which are not affected by illnesses and wax moth, are previously prepared. They are placed in the middle of the bee nest directly behind the combs with brood. They are separated by separating netting for restriction of queen bee's egg-laying. A few days later the comb will be filled with bee pollen. After the bees have sealed the bee pollen with honey, the comb can be moved to another part of the nest, and the new comb can be set on its place for the preparation of the next portion of beebread. During this procedure, it is obligatory to watch if the queen bee has enough space to lay eggs. The disadvantage of this method is a considerable time spending, which causes high cost of the product, as well as the regular intrusion into the work of bee family.

It is known that the beebread reserve of the bee family is created during first half of summer (Івченко, 2002a). Practical experience shows that it is not hard to create a stock of 2-3 beebread combs for each bee family. However, the technological operations of this process depend on the bee management system and the type of the hive. Thus, the general method is used in long hives: the separating netting is placed directly behind the frames with brood and dark-brown comb right next to the netting. After the comb gets filled with beebread, it is replaced with an empty one. If the pollen harvesting falls on the period of intensive spring development of families (May - early June), separating netting and combs for beebread are moved aside to unrestrict the space, which is necessary for breeding.

Practice shows (Таранов, 1986; Бугера, 2001; Івченко, 2002b; Броварський та ін., 2009, 2013) that in double-body and skyscraper hives it is better to accumulate beebread on the hindmost combs of lower case. During the period of intense bee pollen harvesting, the filled combs are ejected and replaced with empty ones. The combs filled with beebread that was removed from beehives are preserved in closed cool room. Before collecting honey they are placed into another case with strong family or into the long hive aside for bees to add honey into beebread cells and seal them. If the second case is not removed from the hive until middle September, bees fill the low-on-honey combs of the lower case with beebread.

The empty combs in lower case stimulate bees to gather pollen. In case of late honey harvesting, strong families are recommended to be moved to other cases, which all the combs from lower case are moved in. The low-on-honey combs are placed into the lower case. There can be also placed 
special constructional combs for this reason at the end of honey gathering. In these frames bees put bee pollen. After the end of pollen harvesting the frames with beebread are moved to stock (Івченко і Левченко, 2003).

Beebread as well as honey-and-beebread combs are better preserved in closed cool apartment, where the temperature doesn't fall below $0^{\circ} \mathrm{C}$. Frozen beebread that was preserved outside the nest of bee family loses a big part of its valuable properties, however such beebread are still consumable for bees. The combs with beebread from constructional frames can be used for feeding bees in spring. Thus, parts with beebread are cut out, put into container for conservation and poured up with honey. In the spring the mixture is combined with warm water, mashed to get a doughy mass, which is fed to bees. For trading, beebread is obtained in combs or in pure form. The first method has a number of disadvantages: strictly determined temperature mode of conservation, limited range of determined humidity, the necessity of protection from wax moth (Кривцов и Лебедев, 1996; Лебедев, 2001; Приймак, 2008).

That is why most specialists prefer obtaining beebread in pure form. Until recently, two main methods of obtaining the beebread have been widely used: with either full or partial filtering of granules from wax fraction. Both methods include the preparation of beebread within the apiary.

Practitioner recommendes to use light, light-brown and brown combs which are almost entirely filled with beebread (Мулявко, 2001). It is not advised to select the cells with pollen those are not completely fermented. It is determined by the visual inspection of beebread cells. In the process of ejection the beebread cells it is not only important to destroy the wax basis of the comb but also to remove its wax shell keeping it unharmed. For this purpose, the most suitable equipment is shredder that has the pins of cylindrical shape as working bodies.

Scientists had developed a special sieving mechanism that allows compressing the beebread cells and destroying their wax shell during the processing of beebread combs. Such method allows excluding the use of machine for separating of the ground wax-beebread mass into fractions from the previously proposed technology (Некрашевич и др., 1988). The beebread can be completely removed from the bee comb with the help of special equipment (Бышов и Каширин, 2012; Некрашевич и др., 2014, 2015a; Мамонов и др., 2016).

Scientists are convinced that the use of proposed method of grinding beebread combs and pneumatic separation with the airflow speed from 7.8 to $8.1 \mathrm{~m} / \mathrm{s}$ allows ejecting no less than $97 \%$ of beebread with the content of wax impurities no more than $2 \%$ and output of unharmed beebread granules no less than $80 \%$ (Приймак, 2008). It is important that the beebread in combs is ripened. The term of its preservation and affection by pathogenic microorganisms depends on the ripeness of beebread. It has been established that ripened beebread has slightly moistened surface of brown colour. The beebread that has not been fermented has a faint surface and is lighter in colour. The prepared combs are preserved in frameworks in special refrigerator units, where the temperature is sustained between 6 and $8{ }^{\circ} \mathrm{C}$. In such conditions beebread combs can be conserved for no less than a year. It is very comfortable to prepare beebread during the honey pumping period because it is expedient to remove honey from the beebread combs before conservation.

The researchers propose a few technologies for removing of beebread from the bee combs (Таранов, 1986; Жоржускене и Кждзяускене, 1990; Кирьянов и Русакова, 1998; Приймак, 2008).

Obtaining the beebread with soaking of combs. This technology is based on the soaking of the comb in the water during the day for its further centrifugation. Then obtained solution of beebread 
is filtered in water from mechanical impurities. After precipitation the water is poured away and wet beebread is dried in specialized lockers. The beebread obtained in such way loses $60 \%$ of its properties and does not have much value in apitherapy, though it can be used as a feed for bees as well as in cosmetology, alcohol and food production

Vacuum technology. This technology consists of drying of beebread in the combs and ejecting it using vacuum. The disadvantages of vacuum technology are the low productivity and the necessity in specialize vacuum units of drying lockers of high price. This technology is not used in Ukraine.

Air filtering technology. The technology of obtaining the beebread in the air lockers features the next operations: beebread combs are dried; cooled; the comb is ejected from the frame and the wire is removed; the comb is grinded on special mills. The obtained mass is ventilated in special air lockers, thus cleaning the beebread from wax. The use of this technology is characterized with the big labor costs, which is not profitable in terms of industrial conditions of production.

Freezing of beebread combs. The only difference between the freezing technology and previous one is that the drying and cooling phases are replaced with freezing of the comb. The disadvantage of this technology is that the beebread loses its biological value as a result of using low temperatures. The use of any of mentioned technologies expect observance of the next requirements: in the process of preparing its necessary to remove honey and nectar if present; selected combs must not have any signs of mold or wax moth; drying of the combs or in pure form is conducted at the temperature no higher than $42{ }^{\circ} \mathrm{C}$; the humidity of dried beebread has to be no more than 14-15\%; cooling of beebread expects its placement into refrigerator under the temperature of $0 \pm 2{ }^{\circ} \mathrm{C}$ for $30-50$ minutes; air ventilation has to be at the speed of $7.8-8.1 \mathrm{~m} / \mathrm{s}$ (this contributes to decrease of wax impurities in beebread up to $2 \%)$.

V.P. Dombrovskyi in 2013 proposed his own developed technology with the use of multifunctional collapsible comb for obtaining beebread. It consists of many plates connected on the ends that have double sided semi cells with bottoms disposed in staggered order (Осташевський, 2006). The disadvantage of this technology is a big number of components, which complicate assembling and disassembling of the comb as well as disables the process of mechanized ejecting of beebread (Броварський та ін., 2015).

G.M. Pryjmak (2008) suggests using mechanical technology for obtaining beebread. It includes the next operations: drying raw product (in combs) at the temperature of $40^{\circ} \mathrm{C}$ during $10-18$ hours until the humidity is $14-15 \%$; cooling of dried product to the negative temperature $\left(-3^{\circ} \mathrm{C}\right)$ and grinding the beebread combs with rollers with the spacing of $4.9-5.0 \mathrm{~mm}$ between them; screening and airing of the grinded material with the machine for seeds refinement with the netting diameter of $2.6 \mathrm{~mm}$; disinfection of beebread with gamma radiation or mixture of ethylene oxide and bromomethane; packing the beebread into glass jars or polyethylene packets. The shelf life of such beebread is 1 year.

The scientists described the technological line for extraction of beebread and the equipment included in it, the technical characteristics of the machines are presented (Некрашевич, 2007; Гайбарян и др. 2011; Некрашевич и др. 2012, 2015b). In conclusion, the known technologies of the production of beebread allow obtaining this product in the conditions of household and industrial apiaries. It has been established technological parameters of preparation of the raw material (combs) and preprocessing of obtained product. The methods of conserving the beebread as a biologically active product need the further improvement. Therefore, the aim of our work was to develop new technological equipment for bee bread production of using artificial comb. 


\section{Materials and methodology}

Scientific issues that were set up during the research have been solved experimentally, using the next methods of research: zootechnical (setting experiments, pollen productivity of bee families, ethological observation of bees working, general observation), construction (development and production of the set of equipment) and analytical (literature review, analysis and generalization of the results of research).

Research, construction equipment and his tests were conducted during 2011-2016. Scientific research base were "Research Apiary of Holosiievo" of the Department of Horse-Breeding and Beekeeping of the National University of Life and Environmental Sciences of Ukraine (Ukraine) and Institute of Biodiversity Conservation and Biosafety of the Slovak University of Agriculture in Nitra (Slovak Republic). Approval of new industrial technology was carried out on bee-farms of different forms of ownership in Ukraine. Currently, technology is patented (no. UA71320) and used by beekeepers in Ukraine.

\section{Results and discussion}

Equipment for obtaining beebread. For obtaining of the beebread using industrial method, composite authors have given up the use of bee combs and set a target to construct a comb for beebread production that would allow us to increase productivity and mechanize the process of ejecting the prepared product in the industrial technology of beebread production. In order to achieve this, there were developed plastic cartridges (Figure 1a), which with the help of holders can be easily connected to each other. One side of the comb is assembled from individual cartridges $(435 \times 300 \mathrm{~mm}, 300 \times 435 \mathrm{~mm}, 435 \times 230 \mathrm{~mm})$, then a polyethylene Backlit membrane (PET) with the thickness of $0.36 \mathrm{~mm}$ is put over and serves as a partition.

Then the second side is put over the membrane. The cartridges assembled into the comb are connected to each other with holders. Such comb is put into the bee family nest to obtained beebread. After the comb gets filled with beebread, it is removed from the hive, the cartridges are then separated and the content of the cells is ejected. This artificial comb has a set of advantages comparing to the prototype. It allows simplification of the construction, mechanization of the process of ejecting the beebread and prevents most of its damage and pollution with mechanical impurities. For ramming of bee pollen and ejecting the beebread from the cells of cartridges, it was developed special equipment, shown on the Figure $1 \mathrm{~b}$.

The device for ramming of the bee pollen and ejecting beebread from the cells of the cartridges of artificial comb consists of the frame, made of stainless steel, on which there are independently moving eliminators of cylindrical form allocated in staggered rows (275 pieces), with a spring of the $30 \mathrm{~mm}$ longwise an $5 \mathrm{~mm}$ in diameter, placed under each of them. The whole mechanism is covered with a lid that has a fixed handle on it. The manual press for removing of the beebread from the cells of the cartridges of artificial comb is constructed in the next way. The slipper of the press that is performed with possibility of vertical rectilinear movement is connected with a puncheon, equipped with a big amount of pistons, allocated like the cells in the comb. Each piston is equipped with a spring with a gentle elastic rating with a possibility of rectilinear movement in the direction that is parallel to the movement direction of the puncheon. In the unloaded state the pistons have to be on the maximum extension. To the base of the press it is connected the holder for the cartridge of the artificial comb. 

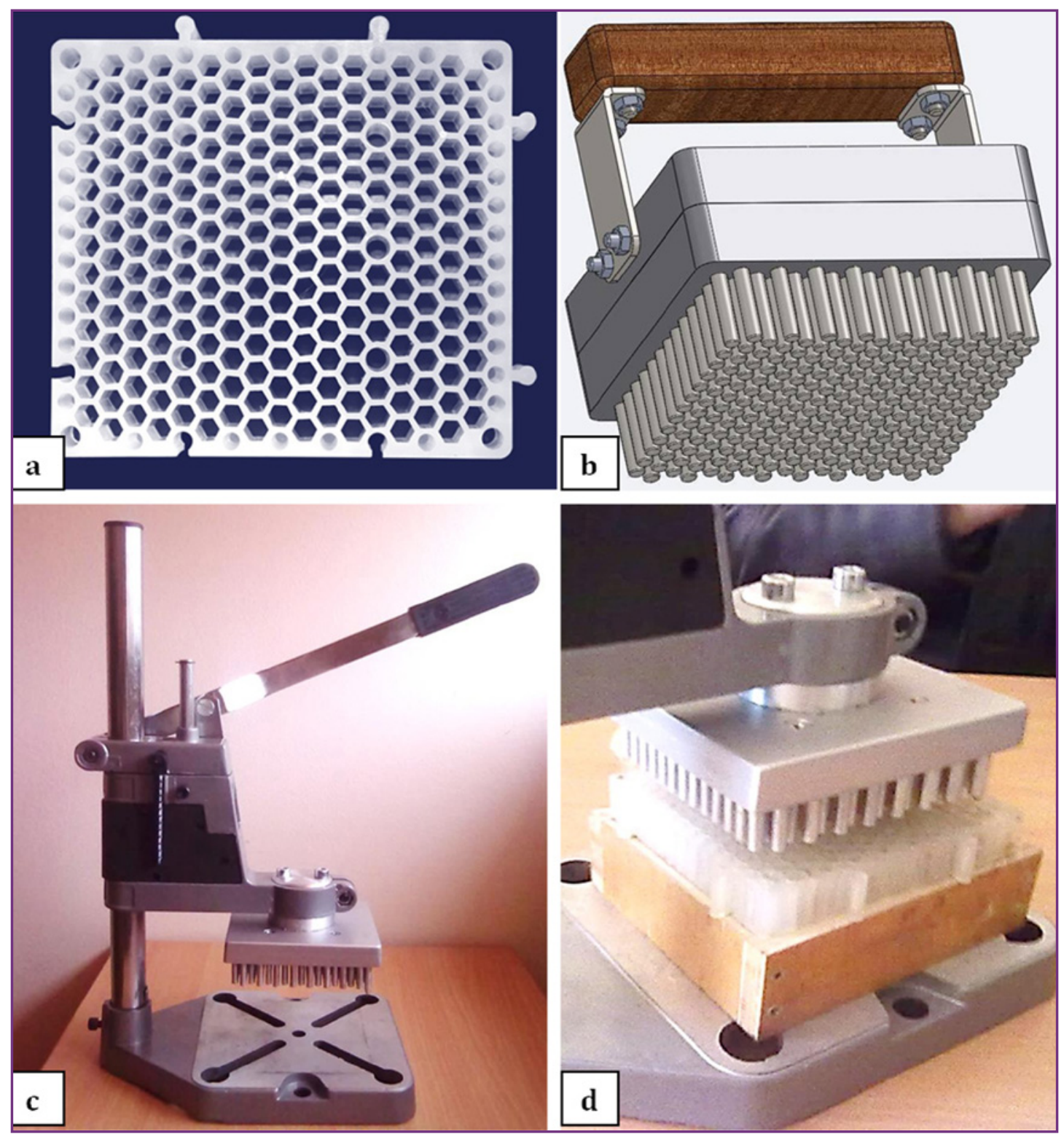

Figure 1

Equipment for beebread industrial technology $a$ - cartridge; $b$ - manual device for bee pollen compression and beebread removing; $c$ - mechanized device for bee pollen compression and beebread removing; $d$ - cartridge in mechanized device

On the holder there can be fixed one or several connected to each other cartridges. The holder is performed in such a way that it doesn't block the access to the cells of artificial comb, and it is also equipped with a container for the collection of the prepared product. The holder also provides the matching of the axis of cells of the comb with an axis of pistons. It is important to pay attention if the extension of the piston in an unloaded state was equal or bigger than the depth of the cell. That is distance from the surface of the comb to the partition membrane. For ramming, the cartridges connected to each other are fixed horizontally in the holder and filled with bee pollen. Then the 
puncheon is moved down. Thus pistons ram the bee pollen with the force depending on the deformation of springs.

After that the puncheon is returned to the starting position. In the process of removing beebread, an individual cartridge is fixed in the holder. Then the puncheon is moved down. Thus, the finished product is removed by pistons into the container. The cartridges free from beebread are later connected to each other and assembled into the comb, which is completed with a partition membrane and used for obtaining the next portion of beebread.

Industrial technology of obtaining beebread. For obtaining of the beebread it is organized the receiving of fresh bee pollen with the help of pollen raps during the first half of spring-summer period, when most polliniferous plants are flowering. In Ukraine it is possible to start gathering the pollen from the middle of May. When the bee families gain the strength of 6-8 bee spaces and have the sufficient (no less than 4-5 kg) feed supply, the hives are equipped with pollen trap with disabled pollen nettings. Very strong families are not recommended to use for pollen gathering as there may happen the violation of flying activity of bees, which precipitates the swarming activation. During the use of pollen trap, the flying appearance and shape changes, which bees have to get used to during first 3-5 days of harvesting campaign. During this period there can be some accumulation or even massive number of bee flying out from the entrance of the hive. After some time though, they gradually begin to fly through the apertures in the netting to the nest and condition returns to normal. After the preparing period, pollen gathering nettings are enabled during all the period of obtaining beebread. Periodic temporary disabling of the nettings during the afternoon when the bees suddenly decrease the amount of gathered pollen is objectionable, as this complicates the activity of the family even more than if the netting is constantly enabled. The short-term periods of bee pollen preparing interchanged with disabling pollen traps, especially when they are removed, are also unwanted. During the period of swarming or insemination flight of the queen, the pollen traps are disabled. A part of pollen, gathered by bees (30-40\% on average) reaches the tray of the pollen trap it is removed from the tray every evening. The prolonged stay of the bee pollen in the tray is objectionable, as it can absorb the moisture or get affected by microorganisms, which leads to the spoilage or decrease in quality of the bee pollen. There can be gathered from 100 to $300 \mathrm{~g}$ of bee pollen from pollen trap every day.

The harvested bee pollen is cleaned from litter and used for beebread production. Further, to obtain the beebread, the artificial comb is prepared (Figure 2), which is placed horizontally on the bottom of the sheet pan and pour the gathered bee pollen onto the whole surface of the cells. Then the bee pollen in evened with a brush and remains are sweeped onto the sheet pan. The bee pollen is then rammed with a press. Then the comb is turned over and the same operations are conducted from the other side. After ramming, the bee pollen is poured again on the same side of the comb. It is evened on the surface of the comb and rammed, the comb is turned over and the procedure is repeated on the other side. To fill the cells of each side of the comb, it is spent about $600 \mathrm{~g}$ of bee pollen. After that, the surface of both sides is greased with liquid honey (or water solution of honey).

The comb is later returned to the nest of bee family, which occupies no more than 6 bee spaces. It is not reasonable to use strong families for obtaining beebread because the bees in such families will intensively use the protein feed placed in the comb to feed the brood. The artificial comb is placed next to the last in the nest, which is right after the covering frame (Figure 3). It is left in the nest for 2-3 days - until the appearance of glitter on the feed. 


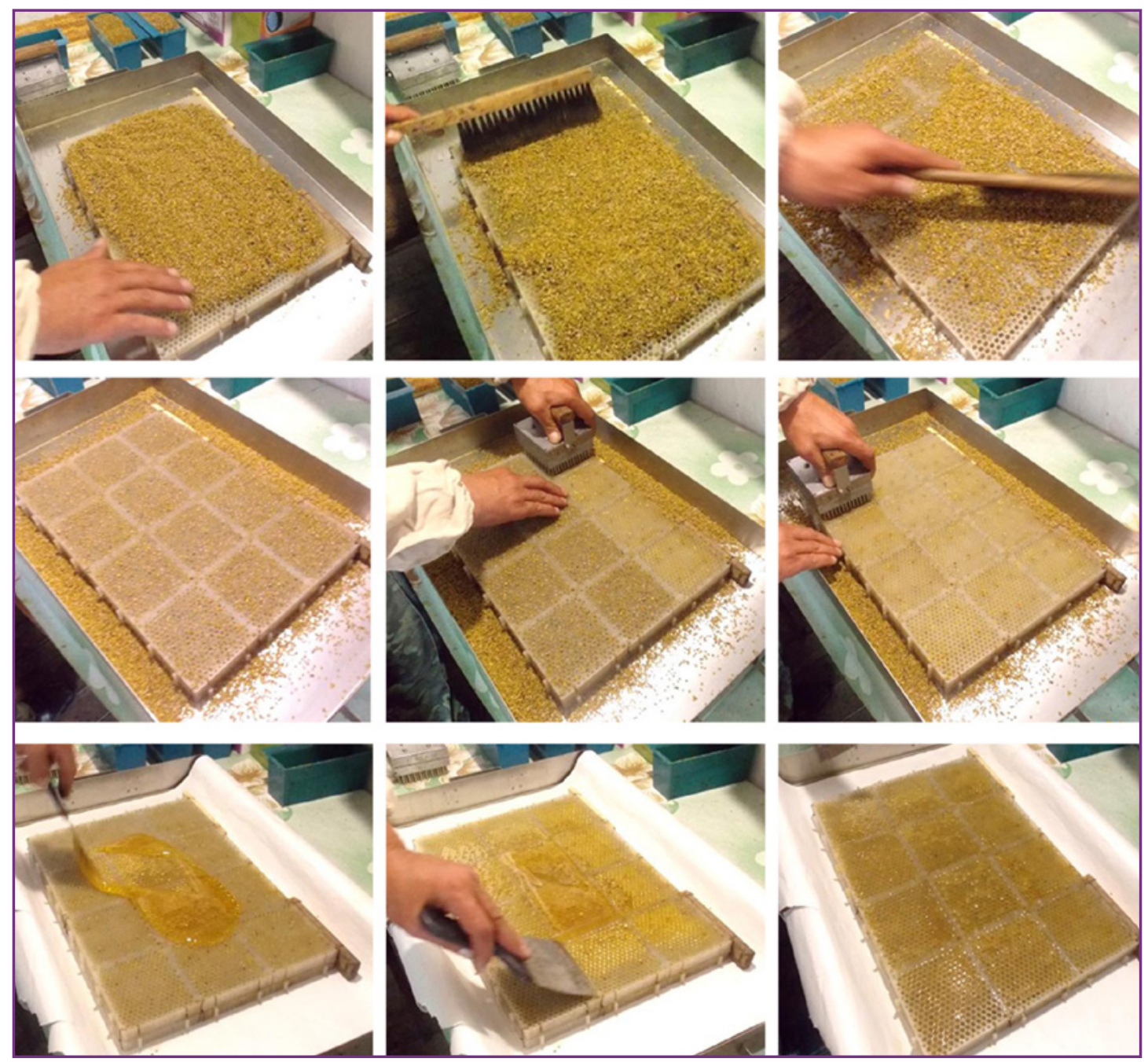

Figure $\mathbf{2}$ Process of filling the comb with the fresh bee pollen and honey

If the bees do no consume the feed, the frame is left in the nest for 14 days until the beebread is ripened. If otherwise the bees consume protein feed, the comb is removed from the nest. For ripening of the beebread the incubator family is used. To provide the ripening of the beebread the strong family with 14-15 more bee spaces is used. The ceiling (heat insulation) is removed from the nest frames, the ventilation netting is put over the top and install the empty case where the artificial combs are placed for the further ripening of the beebread. This case is necessary to be well provided with heat insulation. To prevent the consumption of protein feed, it is possible to place the comb into the netted isolator.

According to the second method, in the comb during the first and following coverings the small amount of pollen is used. It is strewed in such a way so that each cell got from 3 to 5 pollen lumps, which are rammed with a press. Further, from 3 to 5 pollen lumps are added to the cells, where the bees ate him. Then the pollen is rammed again. During 6-8 days the bees fill the cells with beebread. After that, the combs are conserved in the bee families' nests the same way as in the previous method. 
The comb is then left in the nest for 10 days. During this period of time the beebread goes through the fermentation process. Thus, the comb is entirely filled with beebread after the $4^{\text {th }}$ of ramming the bee pollen. However, the disadvantage of this method is a significant labor spent on the execution of the operations of refilling the cells with bee pollen.

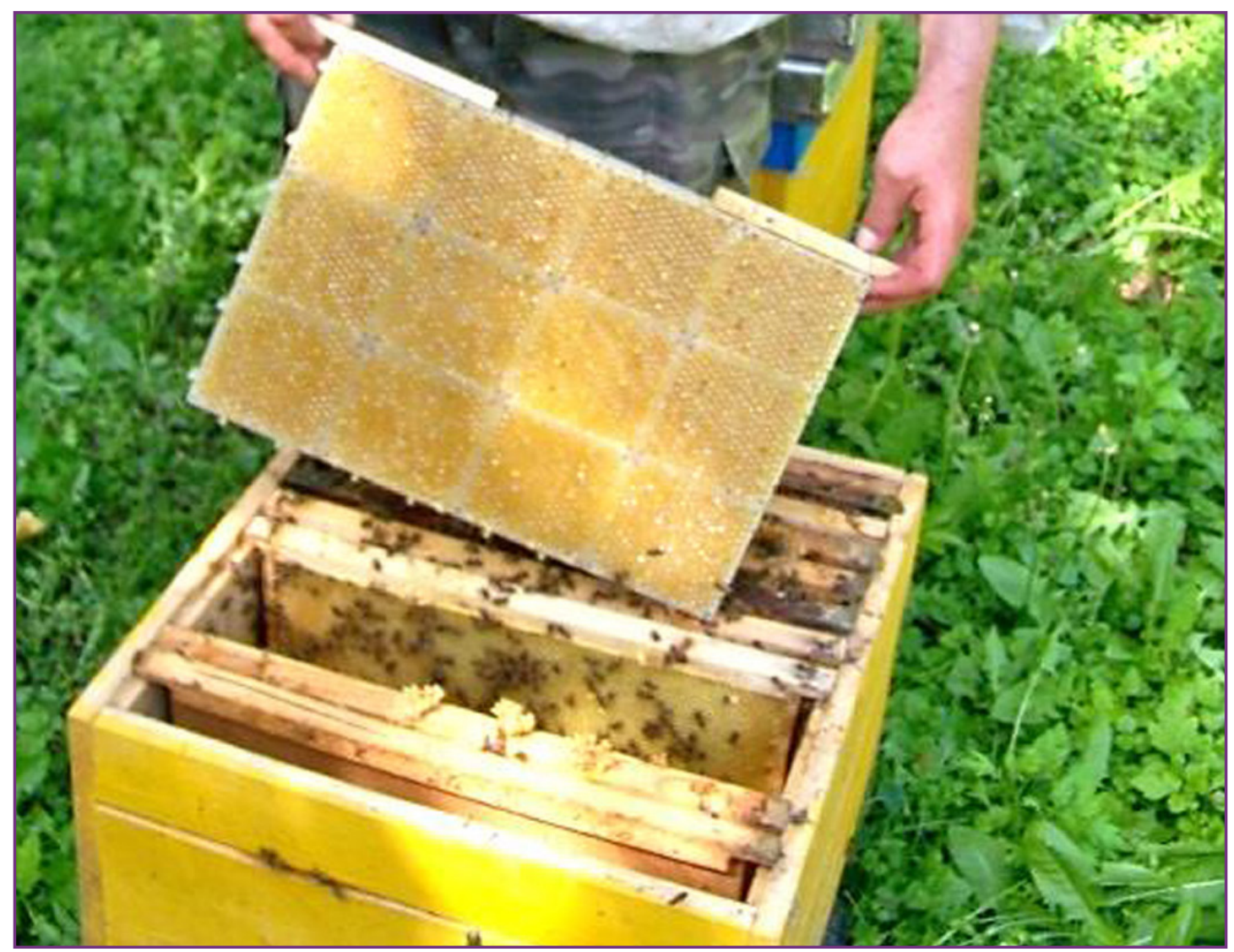

Figure 3

Placement of artificial comb in the nest of bee family

After ripening of the beebread the artificial combs are removed from the nests (Figure 4). The cartridges are separated and with the help of mechanized device for bee pollen compression and beebread removing, equipped with a tray for beebread, the beebread is removed from the cells. The cartridges are then connected to each other, the comb is assemble and again used for obtaining beebread.

The technical solution of this technology is that mechanical ramming of beebread in the cells contributes into the increase of beebread density and with the use of artificial comb from biologically inactive material decrease the chance of wax and other impurities in it. The productivity of such method increases due to the absence of the necessity in thermal (steam generator, refrigerator etc.) and pneumatic (vacuum machine, compressor etc.) equipment, and this, in the absence of moisture and temperature drops influence, contributes into the increase of the quality of the obtained beebread. 


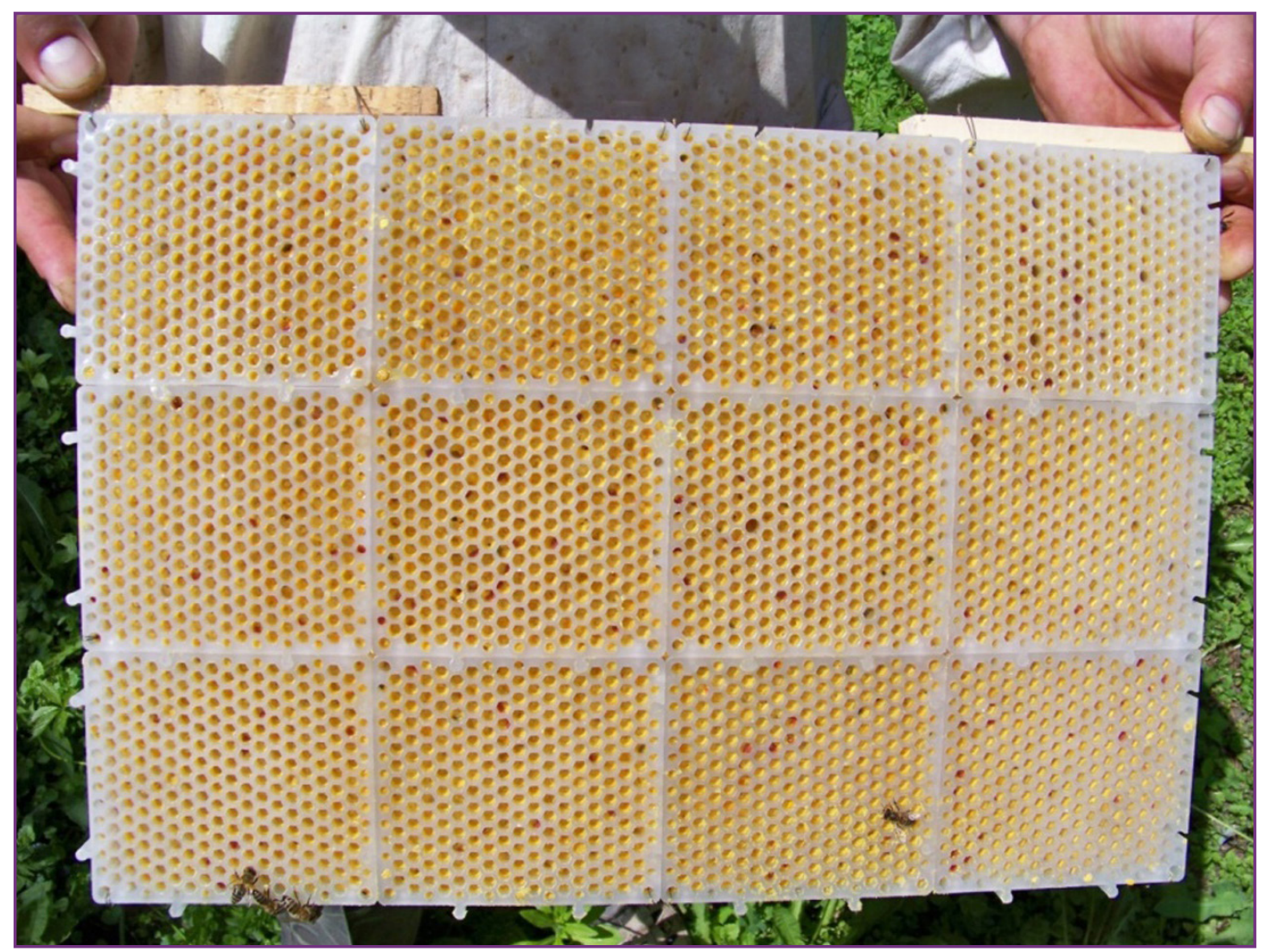

Figure 4 Artificial comb with beebread after maturation

\section{Conclusion}

For the first time the industrial technology of beebread production was developed. Equipment has been designed for the production of beebread, the main element of which is an artificial comb. The optimum technological conditions are determined and a state of the bee family for the production of bee bread.

\section{Acknowledgments}

The publication was prepared with the active participation of researchers involved in the International network AgroBioNet of the Institutions and researchers for realization of research, education and development program «Agrobiodiversity for improving nutrition, health and life quality» TRIVE (ITMS 26110230085) and within the project ITEBIO (ITMS 26220220115).

\section{References}

Brindza, J., Brovarskyi V. 2013. Pollen and bee pollen of some plant species. Kyiv, Korsunskiy vidavnichiy dim «Vsesvit», $137 \mathrm{p}$.

Brindza, J., Schubertova, Z., Brovarskyi, V., Motyleva, S., Mertvischeva, M., Grygorieva O. 2015. Morphological characteristics of common buckwheat (Fagopyrum esculentum Moench) pollen grains and bee pollen. Науковий вісник Національного університету біоресурсів і природокористування України. Серія 
Технологія виробництва і переробки продукції тваринництва, вип. 223, с. 17-24. http://nbuv.gov. ua/UJRN/nvnau_tevppt_2015_223_4

Brovarskij, V., Brindza, J. a i. 2010. Včelí obnôžkový pel.' Vydavatel'stvo - Kyjev - Nitra, FOP I. S. Maidachenko, $288 \mathrm{p}$.

Nikolaieva, N.V., Grygorieva, O.V., Brindza, J., Garkava, K.G., Klymenko, S.V. 2014. Morphological features of pollen Corylus avellana L. and Castanea sativa Mill. as indicator of environmental changes. Плодоводство и ягодоводство России: сборник научных работ, том XXXX, часть 1, с. 232-238.

Redina, N.M., Adamchuk, L.O., Nikolaieva, N.V., Brindza, J. 2016. Morphological characteristics of bee pollen obtained from Brassica napus L. Науковий вісник Львівського національного університету ветеринарної медицини та біотехнологій імені Сз Ґжицького, т. 18, № 2-3, (68), с. 73-78. https:// nvlvet.com.ua/index.php/journal/article/view/728/727

Бабич, І.А., Мегедь, О.Г. 1979. Бджільництво. Видавництво - Київ, Урожай, 248 с.

Балабушка, В.К. 2010. Трав'янисті медоноси та пилконоси України: весняні. Видавництво - Київ, Дім, сад, город, 76 с.

Богомолов, К.В. 2012. Атлас медоносов пчеловода-практика: справочное издание. Издательство Рязанская областная типография, 80 с.

Боярчук, С.В. 2015. Оптимізація забезпечення кормами бджолиних сімей. Науковий вісник НУБіп України, вип. 223, с. 57-64.

Броварський, В., Бріндза, Я., Адамчук, Л., Величко, С., Колеснік, А. 2015. Промислова технологія виробництва перги: методичні рекомендації. Видавництво - Київ, НУБіП України, 27 с.

Броварський, В.Д., Багрій, І.Г. 1995. Розведення та утримання бджіл. Видавництво - Київ, Урожай, 223 c.

Броварський, В.Д., Бріндза, Я., Колесник, А.І., Величко, С.М. (2013). Біохімічні процеси в перзі за різних умов обробки та тривалого зберігання. Матеріали Міжнародної міждисииплінарної науковопрактичної конференції «Вода і здоров'я людини». Видавництво - Ужгород, Патент, с. 232-235.

Броварський, В.Д., Головецький, І.І, Лосєв, О.М., Величко, С.М., Адамчук, Л.О. Степанюк, М.М. 2009. Бджолине обніжжя, виробництво та зберігання. Монографія. Видавництво - Київ, ФОП І.С. Майданченко, 76 с.

Бугера, С.І. 2001. Заготівля та використання стільників з пергою. Пасіка, № 8, с. 18.

Бышов, Н.В., Каширин, Д.Е. 2012. Обоснование рациональных параметров измельчителя перговых сотов. Вестник Красноярского государственного аграрного университета, вып. 6, с. 134-138. https://elibrary.ru/item.asp?id=17806106

Величко, С.М. 2015. Формування запасів перги у гніздах бджолиних сімей. Науковий вісник НУБіП України, вип. 223, с. 81-85.

Гайбарян, М.А., Мишаков, А.А., Гущина И.В. 2011. Технология и оборудование для производства перги. Проблемы механизачии агрохимического обеспечения сельского хозяйства, с. 79-86. https:// elibrary.ru/item.asp?id=17548447

Гречка, Г.М. 2011. Сучасний медозбір і його використання бджолиними сім'ями. Вісник Полтавської державної аграрної академії, №3, с. 63-67. http://www.pdaa.edu.ua/sites/default/files/ visnyk/2011/03/63.pdf

Державна Служба Інтелектуальної Власності України. Штучний стільник для виробничтва перги. Власники патенту: Броварський, В., Величко, С., Бринза Я. Україна. Номер патенту. UA71320. 201207-10. http://uapatents.com/4-71320-shtuchnijj-stilnik-dlya-virobnictva-pergi.html

Жоржускене, А.Э., Кждзяускене, К.В. 1990. Что мы знаем о перге? Пчеловодство, № 7, с. 30-33.

Івченко, В.М. 2002b. Топографія перги в сім'ї медоносної бджоли. Український пасічник, № 1, с. 4-7.

Івченко, В.М., Левченко, І.О. 2003. Стимули, які спонукають бджіл-збиральниць пилку до відкладання обніжжя в чарунки щільників. Український пасічник, №8, с. 2-3. 
Івченко, В.Ма. 2002. Розміщення білкового корму в гнізді медоносної бджоли. Бджільництво. Видавництво - Київ, Аграрна наука, с. 45-48.

Кирьянов, Ю.Н., Русакова, Т.М. 1998. Технология производства и стандартизация продуктов пчеловодства. Издательство - Москва, Колос, 160 с.

Кривцов, Н.И., Лебедев, В.И. 1996. Продукты пчеловодства. Издательство - Москва, Нива России, $253 \mathrm{c}$.

Лебедев В.И. 2001. Биологический потенциал пчелиной семьи по сбору пыльцы и заготовке перги. Итоги и проблемы НИР в пчеловодстве, с. 60-63.

Мамонов Р.А., Торженова Т.В., Хмыров В.Д. 2016. Механизация и экономические аспекты промышленного производства перги. Инновационное развитие современного агропромышленного комплекса России, с. 128-131. https://elibrary.ru/item.asp?id=29219268

Мулявко, Н. О. 2001. Бджолиний хліб. Пасіка, №5, с. 24-25.

Некрашевич, В.Ф. 2007. Механизированная линия для промышленной заготовки перги. Современные направления научно-технического прогресса в пчеловодстве, 311a. https://elibrary.ru/item. asp?id=28923989

Некрашевич, В.Ф., Мамонов, Р.А., Буренин, К.В., Карачун, И.Ф. 2014. Исследование процесса измельчения перговых сотов в агрегате АИП-30. Современные энерго-и ресурсосберегающие, экологически устойчивые технологии и системы сельскохозяйственного производства, с. 131134. https://elibrary.ru/item.asp?id=25103259.

Некрашевич, В.Ф., Мамонов, Р.А., Буренин, К.В., Карачун, И.Ф. 2015а. Исследование процесса измельчения перговых сотов в агрегате АИП-30. Материалы онлайн-конференции, посвященной Дню российской науки, с. 111-113. https://elibrary.ru/item.asp?id=29115953

Некрашевич, В.Ф., Мамонов, Р.А., Буренина, Е.И., Буренин, К.В., Миронов, В.В. 2016. Средства механизации измельчения пчелиных сотов. Инновачионное развитие современного агропромышленного комплекса России, с. 157-162. https://elibrary.ru/item.asp?id=29219565

Некрашевич, В.Ф., Мамонов, Р.А., Коваленко, М.В., Нагаев, Н.Б., Буренин, К.В., Буренина, Е.И. 2015b. Технологическая линия извлечения перги. Пчеловодство, № 9, с. 56-59. https://elibrary.ru/item. asp?id=25100073.

Некрашевич, В.Ф., Мамонов, Р.А., Чепик, А.Г., Торженова, Т.В., Коваленко, М.В. 2012. Перга: технология, оборудование и экономические аспекты её производства. Вестник Ульяновской государственной сельскохозяйственной академии, с. 139-143. https://cyberleninka.ru/article/n/ perga-tehnologiya-oborudovanie-i-ekonomicheskie-aspekty-eyo-proizvodstva

Некрашевич, В.Ф., Стройков, С.А., Бронников, В.И. 1988. Извлечение перги из сотов. Пчеловодство, $£$ № 10, с. 29-30.

Осташевський, М. 2006. Технології від Домбровського. Український пасічник, №11, с. 37.

Поліщук, В.П. Акумова, М.М. 1998. Удосконалення сушіння і зберігання квіткового пилку. Бджільничтво, № 23, с. 208-212.

Прибылова, Е.П., Иванов, Е.С. 2011. Оценка нектаропродуктивности видов растений и травянистых экосистем Рязанской области. Вестник Российского университета дружбы народов, № 2, с. 16-21. https://cyberleninka.ru/article/n/otsenka-nektaroproduktivnosti-vidov-rasteniy-i-travyanistyhekosistem-ryazanskoy-oblasti.

Приймак, Г.М. 2008. Бджоловедення. Настільна книга бджоляра. Видавництво - Київ, Альтерпрес, $638 \mathrm{c}$.

Таранов, Г.Ф. 1986. Корма и кормление пчел. Издательство - Москва, Россельхозиздат, с. 160. 